\title{
Ecophysiology of the benthic amphipod Monoporeia affinis in an open-sea area of the northern Baltic Sea: seasonal variations in body composition, with bioenergetic considerations
}

\author{
Kari K. Lehtonen* \\ Finnish Institute of Marine Research, PO Box 33, FIN-00931 Helsinki, Finland
}

\begin{abstract}
A deep-living, open-sea population of Monoporeia affinis from the northern Baltic Sea was studied for seasonal variations in the gross biochemical, lipid class and elemental composition during 1991 to 1993. The seasonal cycle in the composition of this benthic, deposit-feeding amphipod was largely determined by the brief period of spring phytoplankton bloom sedimentation and the longlasting deficiency of good-quality nutrition during late autumn-early spring. The level (\% dry wt) of lipid was lowest in March-April (21 to $30 \%$, range: interannual variation), increased rapidly in early summer ( 27 to $43 \%$ ) and peaked in the autumn (38 to $44 \%$ ). Reciprocal to lipid, the level of protein was highest in the spring (19 to $29 \%$ ) and lowest in the autumn (17 to $23 \%$ ). Carbon and nitrogen levels followed closely the patterns of lipid and protein, respectively. Triacylglycerols were invariably the main lipid class (67 to $95 \%$ of total lipids), while phospholipids formed 4 to $23 \%$ and other classes $<7 \%$ each. Due to high variability in biochemical composition, the energetic value of the body matter of $M$. affinis showed great seasonal variation. Using body composition and previously determined metabolic rates, calculations showed distinct seasonal and life-cycle variability in the bioenergetic strategy of the amphipods. Interannual variability in the body composition of the amphipods was noted, especially between 1991 and the 2 following years. Previously recorded long-term oscillations in the abundance and biomass of $M$. affinis populations and the relation of these oscillations to pelagic events and sedimentation is discussed in the light of the present results.
\end{abstract}

KEY WORDS: Monoporeia affinis - Benthic amphipod · Baltic Sea $\cdot$ Biochemical composition · Lipid classes - Elemental composition - Bioenergetics - Seasonal variation

\section{INTRODUCTION}

The benthic amphipod Monoporeia affinis (previously Pontoporeia affinis; Bousfield 1989) feeds mainly on detrital organic matter present in the sediment and phytoplankton that reaches the bottom via sedimentation. On northern Baltic Sea soft-bottoms, $M$. affinis is usually the dominant macrobenthic species with densities reaching 10000 ind. $\mathrm{m}^{-2}$ and more (e.g. Ankar \& Elmgren 1975, Andersin et al. 1978, 1984, Elmgren 1978). The amphipod is therefore a key species with regard to energy flow in these areas.

•E-mail: lehtonen@fimr.fi
Monoporeia affinis is semelparous, reproducing usually in early spring, with a life-cycle varying between 1 and 4 yr (e.g. Segerstråle 1937, Andersin et al. 1984, Leonardsson et al. 1988). The abundance and biomass of $M$. affinis populations show long-term oscillations (Andersin et al. 1978, 1984); substantial evidence of a coupling between the intensity of algal blooms and the abundance and biomass of benthic amphipod populations has been obtained from lakes (Johnson \& Wiederholm 1992, Fitzgerald \& Gardner 1993) and from shallow, coastal areas of the Baltic Sea (Cederwall 1977, Elmgren 1978, Sarvala 1986).

A major biological feature of most sub-boreal, temperate aquatic environments is high seasonality in 
primary production; the consequences of this phenomenon are reflected through all levels of ecosystem organization and function. The nourishment of benthic deposit-feeders in open-sea areas is largely dependent on autochthonous food sources. However, because availability of such food varies widely throughout the year, benthic organisms must have efficient energy storage systems to be able to cope with long periods of poor food conditions. Consequently, the bioenergetic strategy of Monoporeia affinis is likely to be strongly governed by environmental conditions, and, furthermore, biochemical composition of the amphipods is likely to reflect food availability.

Lipid accumulation is the most widespread longterm energy storage strategy in aquatic crustaceans and their reproductive potential is largely dictated by lipid content (e.g. review by Sargent \& Henderson 1986; also Gatten et al. 1980). Environmental nutritional conditions directly regulate the breeding success of individuals and, subsequently, population dynamics. Lipid (mainly triacylglycerols) is also the major energy storage component in Monoporeia affinis (Hill et al. 1992, Lehtonen 1995) and its North American counterpart Diporeia hoyi (formerly Pontoporeia hoyi (Bousfield 1989), now distinguished as consisting of several species (M. Quigley pers. comm.); e.g. Gardner et al. 1985b, Gauvin et al. 1989, Quigley et al. 1989].

This study deals with the seasonal and interannual changes in the gross biochemical (lipid and protein), lipid class and elemental (carbon and nitrogen) composition of Monoporela affinis from a deep-living, open-sea population in the northern Baltic Sea. The results of a parallel work on the metabolic characteristics of $M$. affinis (Lehtonen 1996) were used to determine the bioenergetic strategy of the species in the study area.

\section{MATERIAL AND METHODS}

Sampling. Seasonal samples of Monoporeia affinis were collected from RV 'Aranda' on 16 occasions between 17 January 1991 and 28 July 1993 from the Bothnian Sea open-sea station SR5 (northern Baltic Sea. $61^{\circ} 05^{\prime} 00^{\prime \prime} N, 19^{\circ} 35^{\prime} 99^{\prime \prime} E_{i}$ salinity $\sim 6 \%$ ) at the depth of $125 \mathrm{~m}$, using a van Veen grab. The amphipods were rinsed from the sediment using sea water cooled to ambient battom temperature $\left(3\right.$ to $\left.4^{\circ} \mathrm{C}\right)$, sieved gently on a small $0.5 \mathrm{~mm}$ mesh and transferred to the ship's cold laboratory $\left(4^{\circ} \mathrm{C}\right)$, where they were allowed to clear their guts in a sand-bottom aquarium for $24 \mathrm{~h}$. The amphipods were sorted by size to age classes $[1+$ and $2+$ yr olds, and gravid females ( -3 yr olds; analysed with eggs/embryos); the young-of-the-year were not collected], placed into Eppendorf tubes and stored in liquid nitrogen. Analyses for dry weight, lipid, lipid classes, protein, carbon and nitrogen were carried out after lyophilization.

Analytical procedures. Total lipid: Lipids were extracted according to the micromethod developed by Gardner et al. (1985a), with small modifications (Lehtonen 1995). Briefly, lyophilized samples (5 to $15 \mathrm{mg}$ dry wt) of pooled ( 2 to 15 ) individuals were Potter-homogenized in $500 \mu \mathrm{l}$ chlor oform:methanol $(2: 1)$. The homogenate was drawn into microcapillaries and centrifuged $(11000 \times g, 20$ s) to separate tissue debris. The extract was washed once with $20 \%$ volume of $0.9 \% \mathrm{NaCl}$ and centrifuged again to separate the lipidcontaining chloroform column. Subsamples were placed into folio cups, chloroform was evaporated and the weighed residue taken as total lipid after the subtraction of the daily zero-sample value.

Lipid classes: An Iatroscan MK-5 analyzer (Iatron Laboratories, Japan) was used for lipid class analysis. The analytical procedure is described in detail elsewhere (Lehtonen 1995). In short, the lipid extracts $(2 \mu l)$ were spotted on Chromarods (SIII) and developed in solvent systems of varying polarity. The following lipid classes were determined: triacylglycerols (TAG), free fatty acids (FFA), sterols/diacylglycerols (ST/DG), acetone-mobile polar lipids (AMPL; e.g. pigments) and phospholipids (PL).

$\mathrm{NaOH}$-soluble protein: Lyophilized samples (6 to $10 \mathrm{mg}$ dry wt) of individuals (2 to 10) were homogenized in $2 \mathrm{ml} 0.5 \mathrm{~N} \mathrm{NaOH}$. Triplicate $0.5 \mathrm{ml}$ samples were incubated for $1 \mathrm{~h}$ in a water bath $\left(60^{\circ} \mathrm{C}\right)$. From these samples, duplicate $0.2 \mathrm{ml}$ aliquots were diluted with $0.8 \mathrm{ml}$ deionized water (to adjust $\mathrm{pH}$ suitable for analysis) and centrifuged $(11000 \times g, 2 \mathrm{~min}) . \mathrm{NaOH}$ soluble protein was determined by the Coomassie blue method (Bradford 1976; BioRad kit) and the samples were measured spectrophotometrically (Perkin-EImer Lambda 2 UV/VIS) at $595 \mathrm{~nm}$ against a BSA (bavine serum albumin) standard.

Carbon and nitrogen: Carbon and nitrogen levels of the amphipods were measured from duplicate 1 to 2 mg subsamples taken from lyophilized, mortarhomogenized, pooled samples ( 3 to 10 individuals). The analysis was performed using a Heraeus CHN analyser

Population data: Mean dry weights of individuals from different age classes at each sampling date were obtained from a population study carried out simultaneously. The population samples (5 box cores) were stored in 5\% hexamin-buffered formalin for 3 mo prior to analysis, and the amphipods were measured for length, and wet and dry weight (oven-drying). However, this procedure was found to yield significantly lower dry weights compared to results from the lyo- 
philization of freshly collected and frozen material, most likely because of the extensive drainage of body lipids to the formalin solution during storage. An experimentally determined correction factor of 1.58 was therefore applied to convert the 'formalin dry weights' to 'lyophilized dry weights'. The population data will be presented in another paper (A.-B. Ander$\sin \&$ K. K. Lehtonen unpubl.)

Bioenergetic calculations: A parallel study on the metabolism of Monoporeia affinis (Lehtonen 1996) was used for the bioenergetic calculations. A detailed description of the method used for the metabolic measurements is given in Lehtonen (1994). In brief, seasonal experiments were carried out by incubating amphipods in batches of 15 to 20 individuals per vial for $24 \mathrm{~h}$. Consumed $\mathrm{O}_{2}$ and excreted $\mathrm{NH}_{4}{ }^{+}$were measured using Winkler titration and the phenolhypochlorite method of Solórzano (1969), respectively.

Metabolic and biochemical parameters were converted to energy equivalents as follows: $\mathrm{O}_{2}=14.06 \mathrm{~J}$ $\mathrm{mg}^{-1}$ (Gnaiger 1983), $\mathrm{NH}_{4}^{+}=24.87 \mathrm{~J} \mathrm{mg}^{-1}$ (Elliatt \& Davison 1975), lipid $=39.35 \mathrm{~J} \mathrm{mg}^{-1}$ and protein $=$ $23.63 \mathrm{~J} \mathrm{mg}^{-1}$ (Winberg 1971). The remaining body matter was assumed to be mainly chitin, ash and carbohydrates; carbohydrate energy value $\left(17.18 \mathrm{~J} \mathrm{mg}^{-1}\right.$; Winberg 1971) was used to estimate the energy content of the 'rest' fraction.

Oxygen consumption rates were determined using the following equations: $\mu l \mathrm{O}_{2} \mathrm{~d}^{-1}=14.29 \mathrm{~W}^{0.770}$ for October-April, $\mu \mathrm{O}_{2} \mathrm{~d}^{-1}=18.32 W^{0.774}$ for May-September and $\mu \mathrm{O}_{2} \mathrm{~d}^{-1}=13.93 W^{1.030}$ for gravid females $(W=m g$ dry $w t)$. To calculate $\mathrm{NH}_{4}^{+}$excretion by the individuals ( $\mu \mathrm{mol} \mathrm{NH}_{4}^{+} \mathrm{d}^{-1}$ ), intercept values of the excretion versus dry weight power function, calculated for each month using a fixed exponent of 0.750 , were used. Daily values for both physiological rates were determined for a mean-size individual from each year cohort; changes in these rates due to growth and seasonal variations in intercept or slope values were obtained by linear interpolation between the sampling dates. Daily growth rates $\left(\mathrm{mg} \mathrm{d}^{-1}\right.$ ) and the interrelated changes in the contents of the specific biochemical components (accumulation and depletion rates) were obtained in a similar way.

\section{RESULTS}

\section{Seasonal variations in biochemical composition}

Lipid levels and seasonal lipid dynamics

Lipid level (\% dry wt) varied between 15 and 45\%, with lowest levels in March-April (Fig. 1). In late May-mid-June, rapid accumulation of lipid began and peak levels were recorded in August-September. Gravid females (present only in winter) always had lower lipid levels (15 to $20 \%$ ) compared to juveniles.

The total lipid content of individuals ( $\mathrm{mg}$ ind.$^{-1}$ ) showed a marked accumulation in both age groups in June-August, and a steady state in the $1+y r$ olds and an extensive decline in the reproducing $2+y r$ olds in November-March (Fig. 2). Accumulation rates were high in June-August, with annual peaks between 19.0 and $33.2 \mu \mathrm{g} \mathrm{d}^{-1}$ (Table 1). After the summer months, the lipid balance turned negative. Most notably, the reproducing generation (2+ yr olds) lost lipid at the rate of 3.6 to $14.0 \mathrm{\mu g} \mathrm{d}^{-1}$ until brood release. Compared to 1991 and 1993, an earlier peak in the lipid accumulation rate was seen in 1992. The accumulation rates of both $1+$ and $2+$ yr olds were distinctly lower in 1992 (16 June to 9 September) than in 1991 (17 June to 13 August), while the 2+ yr olds in summer 1993 (27 May to 28 July) had, again, a higher rate. These observations could denote either earlier or poorer sedimentation of the 1992 spring bloom compared to 1991 and 1993. However, since the rates are dependent on interannual variability in the weight of individuals and the variable length of sampling intervals, the interannual differences in the rates are only indicative

The reproducing generation of the 1989 cohort lost 62 and $67 \%$ of body lipid and TAG, respectively, between 13 August 1991 and 5 March 1992 (Fig. 2). In a similar way, $64 \%$ of lipid (74\% of TAG) was depleted in the 1990 cohort between 9 September 1992 and 4 March 1993, while $41 \%$ of the loss (40\% of TAG loss) had already occurred by 25 November 1992 .

\section{Lipid class composition}

TAG were the major lipid class at all times of the year (67 to $95 \%$ of total) and correlated significantly with the total lipid levels (Fig. 3d, Table 2). The PL level became more pronounced in winter and spring due to reductions in the TAG pool. The neutral-topolar lipid ratio (TAG+FFA+ST/DG in relation to AMPL+PL) was low in the spring and early summer (range 4.1 to 9.8 ) and peaked in late summer-early autumn (range 7.3 to 23.3 ). The only winter measurement (November 1992: 2+ yr olds: 12.4) showed that the ratio had already started to decline in early winter. The neutral-to-polar lipid ratio was invariably higher in the $2+y$ r olds compared to the $1+y r$ olds. Gravid females had a low ratio in March 1992 and 1993 (3.9 and 3.3, respectively), but a very high ratio (18.4) in November 1992, although the lipid level was low $(22.8 \%)$. The lowest TAG levels recorded were 


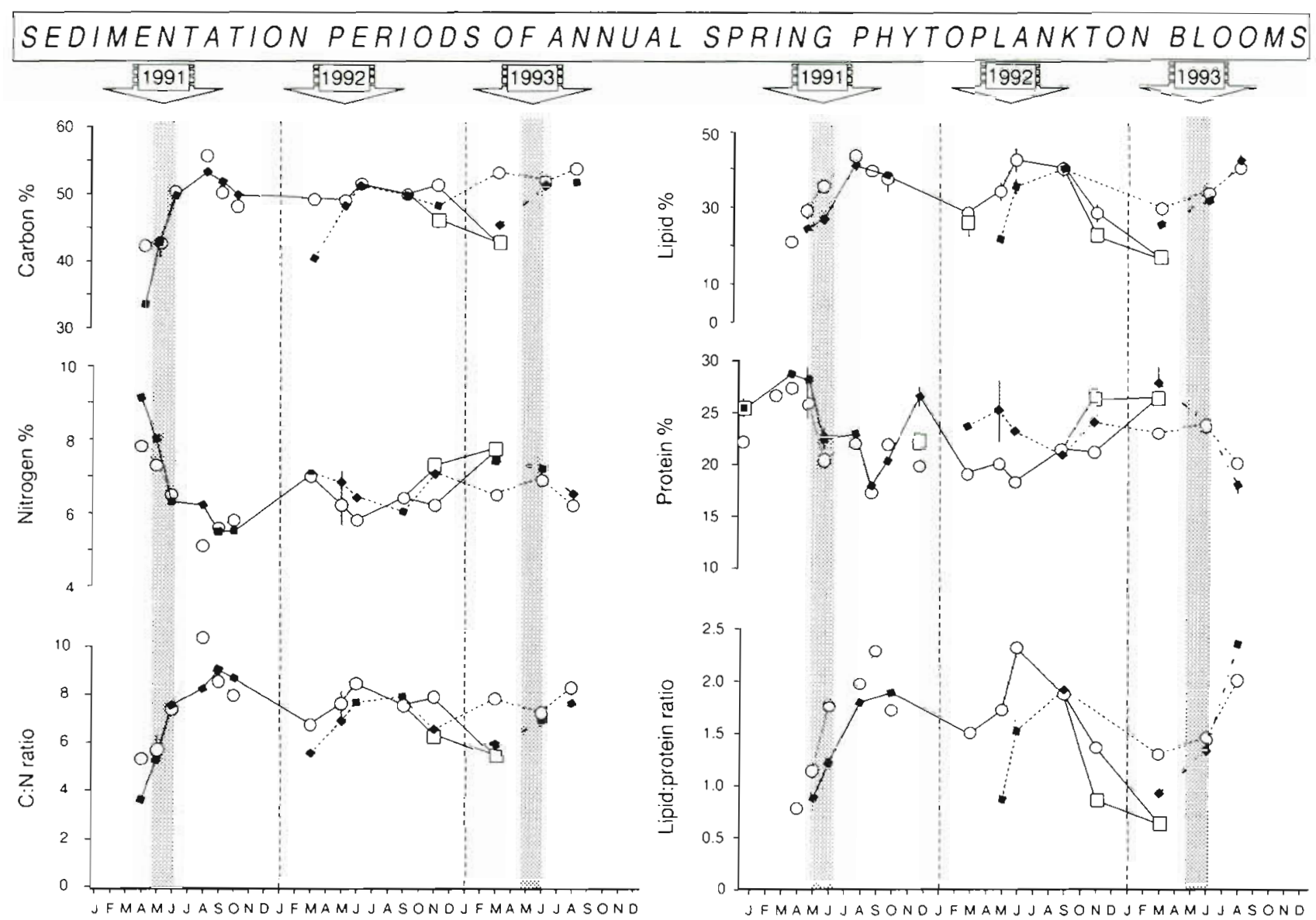

Fig. 1. Monoporeia affinis. Seasonal and interannual variations in the levels (\% dry wt) of elemental (carbon and nitrogen) and biochemical (lipid and protein) constituents, molar C:N ratio and lipid:protein ratio. Standard deviation ( \pm ) is indicated by a vertical bar unless smaller than the symbol size. Shaded bars represent the periods of spring phytoplankton bloom sedimentation in 1991 and 1993 (FIMR unpubl. data). For 1992, the sedimentation period is based on assumption only. (D) $1+$ yr olds; (O) 2+ yr olds;

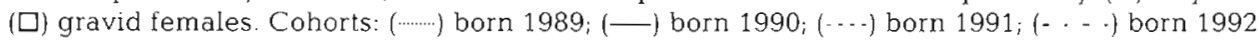

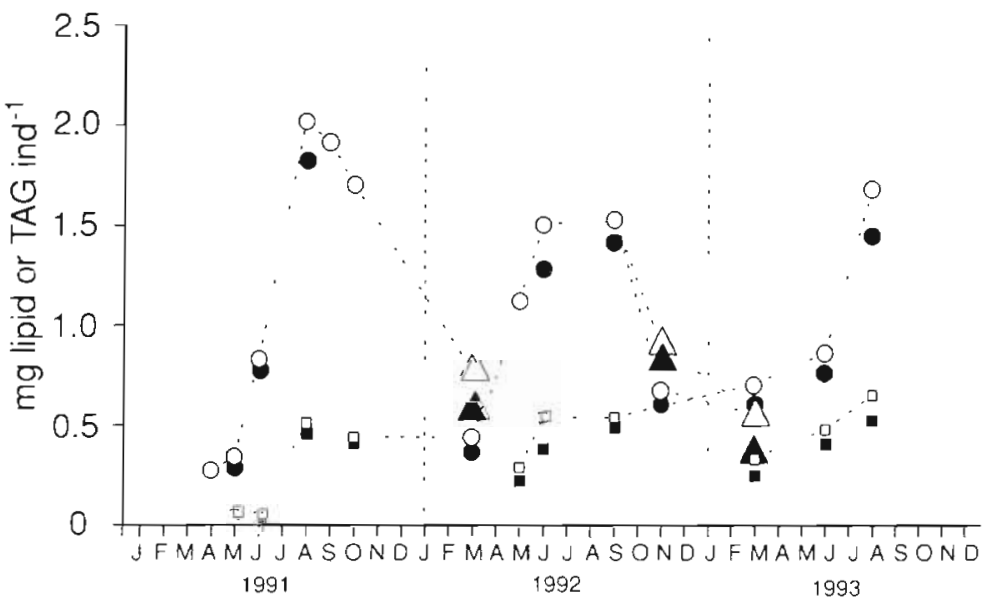

Fig. 2. Monoporeia affinis. Seasonal and interannual varations in the lipid (open symbols, broken line) and triacylglycerol (TAG, filled symbols, no line) content ( $\mathrm{mg}$ ind $^{-1}$ ). Squares: $1+$ yr olds; circles: $2+$ yr olds; triangles: gravid females those measured for gravid females in March 1993 (67.0\%).

FFA and ST/DG together accounted for $<7 \%$, which agreed with previous studies (Quigley et al. 1989, Hill et al. 1992). The markedly high FFA level in June 1992 samples (Table 2: 1+ yr olds: $11.6 \%$ ) could be due to error in the storage or preparation of these samples causing partial hydrolysation, since similar levels were not detected in 1991 and 1993.

The level of AMPL is usually slightly elevated after the sedimentation of the spring bloom, indicating uptake of pigments. The amphipods also turned yellower, and the colour remained until the end of the summer An increase in the pigment content of benthic macrofauna as a response to sedimentation is common (e.g. Ansell 1974, 
Table 1. Monoporeia affinis. Lipid accumulation rates $\left(\mathrm{\mu g} \mathrm{d}^{-1}\right)$ in different year cohorts. obtained by using linear interpolation of changes in dry weight and lipid level ( $\%$ dry wt) between each sampling date, and calculating a mean daily rate for each period

\begin{tabular}{|c|c|c|c|c|c|}
\hline Cohort born 1989 & $\begin{array}{c}\text { Lipid } \\
\left(\mu \mathrm{g} \mathrm{d}^{-1}\right)\end{array}$ & Cohort born 1990 & $\begin{array}{c}\text { Lipid } \\
\left(\mu g d^{-1}\right)\end{array}$ & Cohort born 1991 & $\begin{array}{c}\text { Lipid } \\
\left(\mu g \mathrm{~d}^{-1}\right)\end{array}$ \\
\hline 1991 & & 1991 & & & \\
\hline $11 \mathrm{Apr}-22 \mathrm{May}$ & 1.6 & & & & \\
\hline 22 May-17 Jun & 20.0 & 22 May-17 Jun & 1.9 & & \\
\hline 17 Jun-13 Aug & 23.5 & 17 Jun-13 Aug & 7.3 & & \\
\hline 13 Aug-24 Sep & -0.5 & $13 \mathrm{Aug}-22 \mathrm{Oct}$ & 1.3 & & \\
\hline 24 Sep-22 Oct & -4.8 & 22 Oct-5 Mar (1992) & -1.4 & & \\
\hline \multirow[t]{10}{*}{22 Oct-5 Mar (1992) } & -14.0 & & & & \\
\hline & & 1992 & & 1992 & \\
\hline & & 5 Mar-28 May & 1.8 & & \\
\hline & & 28 May-16 Jun & 33.2 & 28 May-16 Jun & 10.6 \\
\hline & & 18 Jun-9 Sep & 3.8 & 16 Jun-9 Sep & 3.8 \\
\hline & & $9 \mathrm{Sep}-25 \mathrm{Nov}$ & -7.9 & $9 \mathrm{Sep}-25 \mathrm{Nov}$ & -2.4 \\
\hline & & 25 Nov-4 Mar (1993) & -3.6 & 25 Nov-4 Mar (1993) & -0.3 \\
\hline & & & & 1993 & \\
\hline & & & & 4 Mar-27 May & 2.1 \\
\hline & & & & 27 May-28 Jul & 19.0 \\
\hline
\end{tabular}

Christensen \& Kanneworff 1985). However, due to the low AMPL content, variations between measurements were high. For an unknown reason, individuals measured in March 1993 also had an elevated AMPL level. It is possible that AMPL in Monoporeia affinis is an indicator of the quality of the recently ingested food (i.e. fresh material relative to older, more refractory material), but the verification of this would need a more sophisticated study approach.
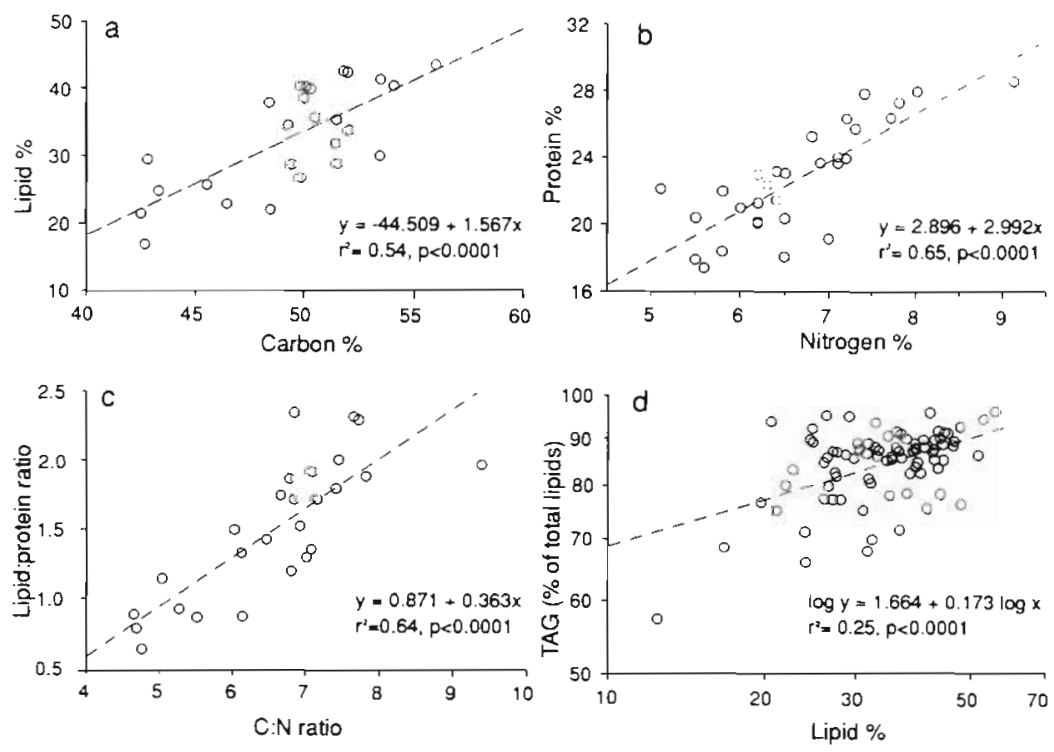

Fig. 3. Monoporeia affinis. Regression analyses on (a) carbon vs lipid; (b) nitrogen vs protein; (c) C:N ratio vs lipid:protein ratio; and (d) lipid (\%) vs triacylglycerol $(\%), r^{2}=$ coefficient of determination, $\mathrm{p}=$ significance at $95 \%$ level

\section{Protein}

The level of protein ranged between 17.4 and $28.7 \%$, mostly due to seasonality, but also to body size. Using the common factor 6.25 for converting nitrogen to protein, significantly greater protein values are obtained; Berges et al. (1993) pointed out that the Bradford method used here is a much less sensitive detector of small peptides and free amino acids than, for example, the method of Lowry et al. (1951), which yields up to $50 \%$ greater 'protein' values.

\section{Carbon and nitrogen}

Carbon (33.5 to $55.9 \%$ ) and nitrogen (5.1 to $9.1 \%$ ) levels followed the changes in the lipid and protein levels respectively, with significant correlations (Fig. 3a, b). The molar C: $\mathrm{N}$ ratio was lowest in April 1991 (3.7), while in March-May 1992 and 1993 the ratio was higher, coinciding with a higher lipid level. The ratio rose rapidly during the summer and annual peaks were recorded between August and November [generally $>7$, with the highest ratio in August 1991 (10.95)]. The C:N ratio correlated significantly with the lipid: protein ratio (Fig. 3c). Gravid females showed lower $\mathrm{C}: \mathrm{N}$ ratios in comparison with the coexisting juveniles. 
Table 2. Monoporeia affinis. Seasonal variation in lipid class composition. Mean values \pm SD (italics). $n=n u m b e r$ of determinations; Weight $=$ mean dry weight of measured individuals $(\mathrm{mg}) ; \mathrm{G}=$ gravid females; $\mathrm{TAG}=$ triacylglycerols; $F F A=$ free fatty acids; $\mathrm{DG} / \mathrm{ST}=$ diacylglycerols/sterols; $\mathrm{AMPL}=$ acetone-mobile polar lipids $; \mathrm{PL}=$ phospholipids $;$ NL:PL $=$ neutral-to-polar lipid ratio

\begin{tabular}{|c|c|c|c|c|c|c|c|c|c|c|}
\hline Date & & Age & Weight & $\mathrm{n}$ & TAG & FFA & DG/ST & AMPL & PL & NL:PL \\
\hline \multirow[t]{4}{*}{1991} & 22 May & $2+$ & 1.53 & 6 & $\begin{array}{r}84.4 \\
4.2\end{array}$ & $\begin{array}{l}3.8 \\
3.9\end{array}$ & $\begin{array}{l}1.4 \\
1.4\end{array}$ & $\begin{array}{l}0.6 \\
0.3\end{array}$ & $\begin{array}{l}9.8 \\
1.6\end{array}$ & $\begin{array}{l}8.85 \\
1.46\end{array}$ \\
\hline & 17 Jun & $2+$ & 2.39 & 6 & $\begin{array}{r}88.2 \\
1.3\end{array}$ & $\begin{array}{l}1.2 \\
0.9\end{array}$ & $<0.5$ & $\begin{array}{l}4.1 \\
1.2\end{array}$ & $\begin{array}{l}5.9 \\
1.4\end{array}$ & $\begin{array}{l}9.11 \\
1.30\end{array}$ \\
\hline & 13 Aug & $1+$ & 0.39 & 3 & $\begin{array}{r}90.9 \\
1.3\end{array}$ & $<0.5$ & $<0.5$ & $\begin{array}{l}1.5 \\
0.5\end{array}$ & $\begin{array}{l}7.7 \\
0.9\end{array}$ & $\begin{array}{r}10.13 \\
1.42\end{array}$ \\
\hline & $13 \mathrm{Aug}$ & $2+$ & 4.28 & 3 & $\begin{array}{r}90.7 \\
1.0\end{array}$ & $\begin{array}{l}3.2 \\
0.5\end{array}$ & $\begin{array}{l}1.9 \\
0.1\end{array}$ & $<0.5$ & $\begin{array}{l}4.1 \\
0.7\end{array}$ & $\begin{array}{r}23.31 \\
3.97\end{array}$ \\
\hline \multirow[t]{10}{*}{1992} & 5 Mar & $2+$ & 1.20 & 4 & $\begin{array}{r}83.7 \\
3.6\end{array}$ & $\begin{array}{l}1.6 \\
1.6\end{array}$ & $\begin{array}{l}1.9 \\
1.2\end{array}$ & $<0.5$ & $\begin{array}{r}12.6 \\
2.7\end{array}$ & $\begin{array}{l}7.09 \\
1.44\end{array}$ \\
\hline & $5 \mathrm{Mar}$ & C & 2.84 & 3 & $\begin{array}{r}79.2 \\
2.7\end{array}$ & $<0.5$ & $<0.5$ & $<0.5$ & $\begin{array}{l}20.3 \\
23.0\end{array}$ & $\begin{array}{l}3.90 \\
0.62\end{array}$ \\
\hline & 28 May & $1+$ & 0.69 & 3 & $\begin{array}{r}77.2 \\
4.9\end{array}$ & $\begin{array}{l}4.3 \\
1.0\end{array}$ & $\begin{array}{l}2.7 \\
0.4\end{array}$ & $<0.5$ & $\begin{array}{r}15.1 \\
2.7\end{array}$ & $\begin{array}{l}5.75 \\
1.48\end{array}$ \\
\hline & 28 May & $2+$ & 1.46 & 3 & $\begin{array}{r}87.3 \\
1.3\end{array}$ & $\begin{array}{l}2.0 \\
1.1\end{array}$ & $\begin{array}{l}1.4 \\
0.6\end{array}$ & $<0.5$ & $\begin{array}{l}8.9 \\
0.4\end{array}$ & $\begin{array}{l}9.82 \\
0.43\end{array}$ \\
\hline & 16 Jun & $1+$ & 0.93 & 3 & $\begin{array}{r}70.0 \\
1.6\end{array}$ & $\begin{array}{r}11.6 \\
0.4\end{array}$ & $\begin{array}{l}4.4 \\
0.7\end{array}$ & $\begin{array}{l}1.0 \\
0.5\end{array}$ & $\begin{array}{r}13.1 \\
2.5\end{array}$ & $\begin{array}{l}6.33 \\
1.31\end{array}$ \\
\hline & 16 Jun & $2+$ & 2.67 & 3 & $\begin{array}{r}84.6 \\
1.6\end{array}$ & $\begin{array}{l}4.7 \\
1.0\end{array}$ & $\begin{array}{l}2.3 \\
0.8\end{array}$ & $\begin{array}{l}0.5 \\
0.1\end{array}$ & $\begin{array}{l}7.9 \\
0.5\end{array}$ & $\begin{array}{l}3.89 \\
0.34\end{array}$ \\
\hline & 9 Sep & $1+$ & 1.58 & 3 & $\begin{array}{r}91.5 \\
1.1\end{array}$ & $<0.5$ & $<0.5$ & $<0.5$ & $\begin{array}{l}8.4 \\
1.1\end{array}$ & $\begin{array}{r}11.01 \\
1.72\end{array}$ \\
\hline & $9 \mathrm{Sep}$ & $2+$ & 3.88 & 5 & $\begin{array}{r}94.1 \\
2.5\end{array}$ & $\begin{array}{l}0.5 \\
0.6\end{array}$ & $<0.5$ & $\begin{array}{l}0.5 \\
0.1\end{array}$ & $\begin{array}{l}4.5 \\
1.5\end{array}$ & $\begin{array}{r}20.82 \\
6.04\end{array}$ \\
\hline & 25 Nov & $1+$ & 2.26 & 6 & $\begin{array}{r}90.2 \\
3.6\end{array}$ & $\begin{array}{l}1.1 \\
1.3\end{array}$ & $\begin{array}{l}0.8 \\
0.8\end{array}$ & $<0.5$ & $\begin{array}{l}7.6 \\
2.2\end{array}$ & $\begin{array}{r}12.43 \\
3.30\end{array}$ \\
\hline & 25 Nov & $\mathrm{G}$ & 4.31 & 2 & $\begin{array}{r}94.7 \\
0.8\end{array}$ & $<0.5$ & $<0.5$ & $<0.5$ & $\begin{array}{l}5.2 \\
0.7\end{array}$ & $\begin{array}{r}18.44 \\
2.97\end{array}$ \\
\hline \multirow[t]{7}{*}{1993} & $4 \mathrm{Mar}$ & $1+$ & 1.15 & 3 & $\begin{array}{r}73.8 \\
5.4\end{array}$ & $\begin{array}{l}4.2 \\
3.0\end{array}$ & $\begin{array}{l}1.4 \\
1.1\end{array}$ & $\begin{array}{l}6.8 \\
4.4\end{array}$ & $\begin{array}{r}15.3 \\
3.3\end{array}$ & $\begin{array}{l}4.12 \\
1.57\end{array}$ \\
\hline & $4 \mathrm{Mar}$ & $2+$ & 1.52 & 6 & $\begin{array}{r}86.7 \\
2.7\end{array}$ & $\begin{array}{l}1.8 \\
1.1\end{array}$ & $<0.5$ & $\begin{array}{l}1.6 \\
1.4\end{array}$ & $\begin{array}{l}9.7 \\
1.1\end{array}$ & $\begin{array}{l}8.03 \\
1.22\end{array}$ \\
\hline & $4 \mathrm{Mar}$ & $G$ & 3.87 & 3 & $\begin{array}{r}67.0 \\
7.4\end{array}$ & $\begin{array}{l}5.1 \\
0.3\end{array}$ & $\begin{array}{l}1.8 \\
1.5\end{array}$ & $\begin{array}{l}2.7 \\
2.8\end{array}$ & $\begin{array}{r}23.3 \\
6.1\end{array}$ & $\begin{array}{l}3.30 \\
1.38\end{array}$ \\
\hline & 27 May & $1+$ & 1.55 & 3 & $\begin{array}{r}84.7 \\
2.8\end{array}$ & $\begin{array}{l}1.7 \\
0.1\end{array}$ & $<0.5$ & $\begin{array}{r}2.9 \\
1.3\end{array}$ & $\begin{array}{r}10.7 \\
1.5\end{array}$ & $\begin{array}{l}6.64 \\
1.41\end{array}$ \\
\hline & 27 May & $2+$ & 2.61 & 3 & $\begin{array}{r}87.4 \\
1.5\end{array}$ & $\begin{array}{l}1.1 \\
0.2\end{array}$ & $<0.5$ & $\begin{array}{l}2.1 \\
1.1\end{array}$ & $\begin{array}{l}9.5 \\
1.8\end{array}$ & $\begin{array}{l}7.77 \\
1.01\end{array}$ \\
\hline & $28 \mathrm{Jul}$ & $1+$ & 1.52 & 6 & $\begin{array}{r}81.1 \\
5.1\end{array}$ & $\begin{array}{l}4.0 \\
1.5\end{array}$ & $\begin{array}{l}2.0 \\
0.7\end{array}$ & $\begin{array}{l}1.0 \\
0.7\end{array}$ & $\begin{array}{r}12.1 \\
3.0\end{array}$ & $\begin{array}{l}7.32 \\
2.57\end{array}$ \\
\hline & $28 \mathrm{Jul}$ & $2+$ & 4.14 & 6 & $\begin{array}{r}86.4 \\
2.6\end{array}$ & $\begin{array}{l}1.3 \\
0.4\end{array}$ & $\begin{array}{l}1.3 \\
0.2\end{array}$ & $<0.5$ & $\begin{array}{r}11.0 \\
2.3\end{array}$ & $\begin{array}{l}8.54 \\
2.05\end{array}$ \\
\hline
\end{tabular}

\section{Energy content and energetic value of body matter}

Lipid formed the major energy component at all times, except in gravid females. The development in the energy content of mean-size individuals ( $\mathrm{J}$ ind. ${ }^{-1}$ ) showed very similar seasonal patterns between different cohorts (Fig. 4); the interannual variability was determined in general by differences in the size of the individuals (Andersin \& Lehtonen unpubl.).

The energetic value of the body matter of Monoporeia affinis shows substantial seasonal fluctuations, with highest values in late summer $\left(28.2 \mathrm{~J} \mathrm{mg}^{-1}\right)$ and lowest in spring (22.5 $\mathrm{J} \mathrm{mg}^{-1}$ ) (Fig. 5). The 2+ yr olds of the 1989 cohort showed, in 1991, markedly lower values in spring compared to the 2 following annual cohorts, but the peak values in summer were stable between the years. The energetic value of the $1+y r$ olds is invariably smaller compared to the $2+$ yr olds until the latter enter their reproductive phase. In comparison with cohort 1989, the gravid females of the 1990 cohort showed a more striking decline in energetic value as the moment of offspring release approached. 


\section{Energy dynamics}

Fig. 6 shows the mean daily metabolic requirements of mean-sized individuals, the net accumulation rates of biochemical components and, in the case of net depletion of energy reserves, the contributions of specific components in energy metabolism. The $1+$ yr olds of the 1990 cohort accumulated surplus energy between 17 June and 22 October 1991. Between 22 October and 7 December 1991, $47 \%$ of the metabolic energy was derived from the combustion of body components, mainly lipid $(32 \%)$. In the $1+y$ y olds of the 1991 cohort, body reserves supported $48 \%$ of energy needs between 9 September and 25 November 1992, but in this case all the energy was derived from lipids.

In the $2+y r$ olds of the 1990 cohort, intensive accumulation of energy occurred between 16 June and 9 September 1992. Between 9 September and 25 November 1992, lipid stores supplied $60 \%$ of their metabolic requirements. In the 1989 cohort, however, lipid depletion accounted for only $15 \%$ of metabolic energy of $2+\mathrm{yr}$ olds at a corresponding time 24 September to

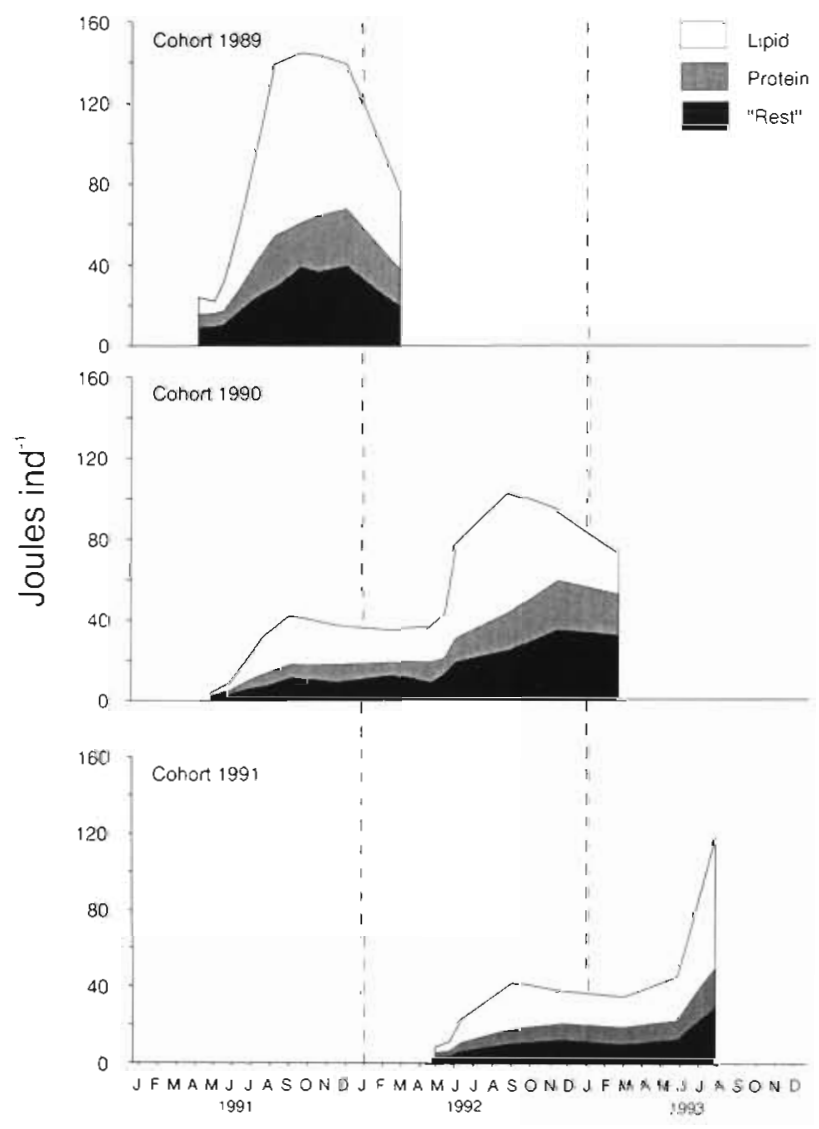

Fig. 4. Monoporeia affinis. Development in the energy content $\left(\mathrm{J}\right.$ ind $\left.{ }^{-1}\right)$ of mean-size individuals representing different year cohorts, fractionated to main biochemical constituents (lipid, protein and 'rest')
7 December 1991). Between 25 November 1992 and 4 March 1993, reserve lipid supported the metabolism of the now gravids of the 1990 cohort by only $26 \%$, and the combustion of protein had intensified markedly (10\% contribution to metabolic needs, seen also as an elevated $\mathrm{NH}_{4}{ }^{+}$excretion rate of gravids; Lehtonen 1996). In the gravids of the 1989 cohort, however, lipid and protein accounted for 64 and $20 \%$, respectively.

\section{DISCUSSION}

\section{Effects of benthic nutritional conditions on Monoporeia affinis}

The results indicate that the sedimentation of the spring bloom has a marked effect on the growth and composition of Monoporeia affinis, while the metabolic response (accelerated $\mathrm{O}_{2}$ uptake and $\mathrm{NH}_{4}{ }^{+}$ excretion rates) is also distinct (Lehtonen 1996). Sediment nitrogen enrichment has been shown to enhance the growth and organic content of benthic invertebrates (Tenore 1977. Tsutsumi et al. 1990 O'Connor 1992). Studies carried out in parallel with the present study show that, at the study station in 1991 and 1993, 70 to $90 \%$ of the annual sedimentation of nitrogen and carbon occurred between early May and mid-June (Finnish Institute of Marine Research. FIMR, unpubl. dataj. Towards autumn and winter marked reductions in the $C: N$, nitrogen and chlorophyll a content of the settling material and in the sediment surface layer were observed. This data is in accordance with previous research on primary production, phytoplankton dynamics and sedimentation in the northern Baltic Sea (e.g. Lassig et al. 1978 Kuparinen et al. 1984, Leppänen 1988, Andersson \& Rudehäll 1993, Heiskanen \& Kononen 1994). Seasonality in the body composition and energetics of $M$. affinis is strongly influenced by pelagic processes,

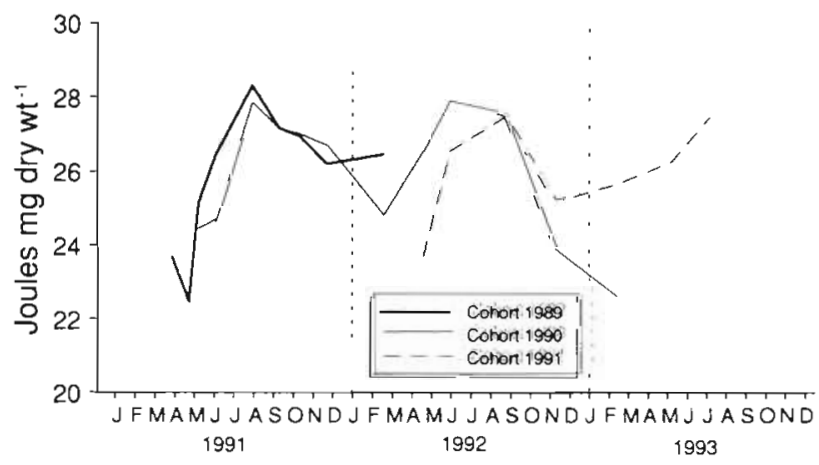

Fig. 5. Monoporeia affinis. Variations in the energetic value of the body matter $\left(\mathrm{J}\right.$ mg dry $\left.\mathrm{wt}^{-1}\right)$ of mean-size individuals representing different year cohorts 


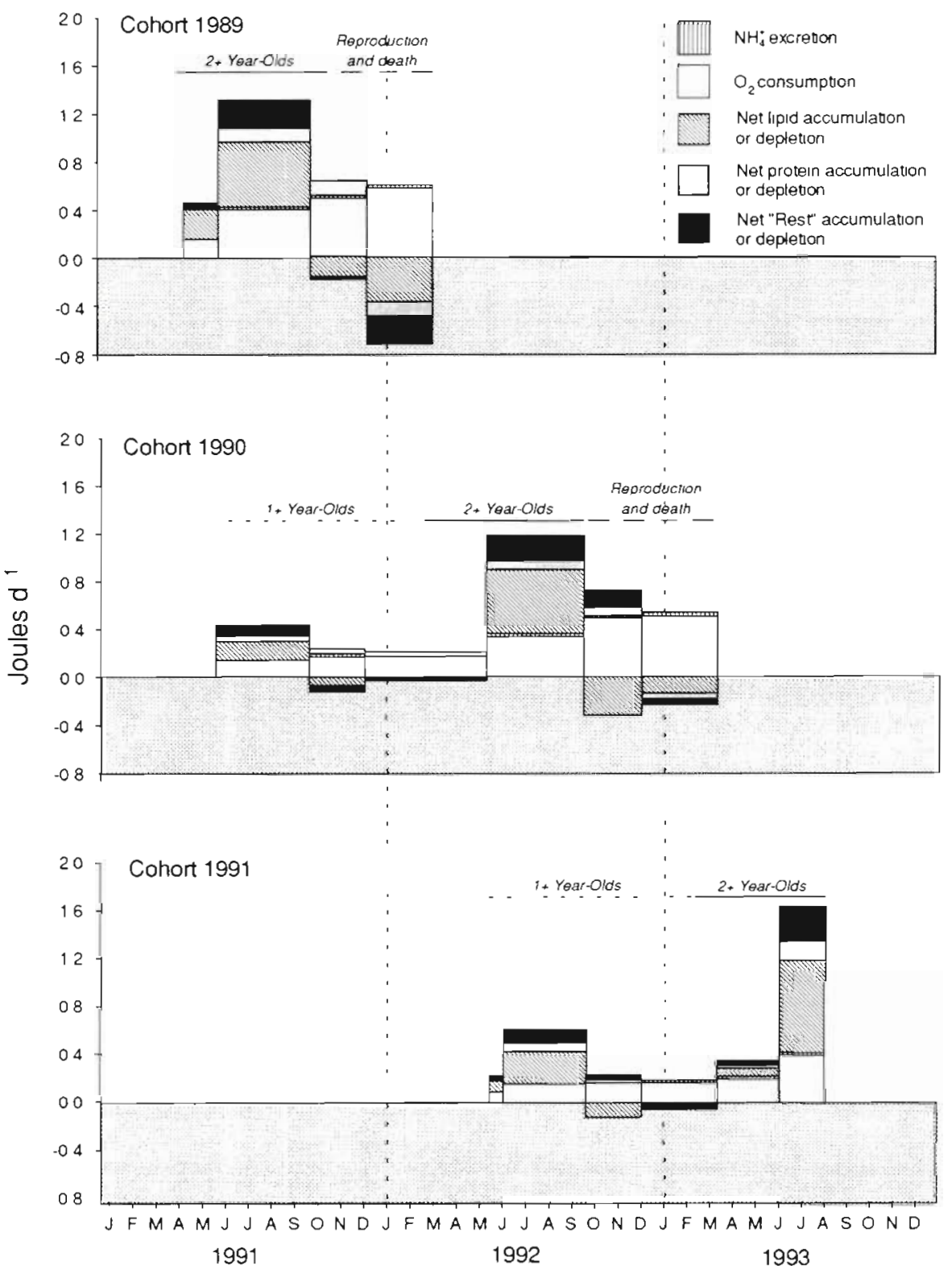

Fig. 6. Monoporeia affinis. Mean daily energy partitioning ( $\mathrm{J}$ ind ${ }^{-1}$ $\mathrm{d}^{-1}$ ) calculated for mean-size individuals from different year cohorts. The sum of $\mathrm{O}_{2}$ consumption and $\mathrm{NH}_{4}{ }^{+}$excretion represents the daily energetic requirements; net energy accumulation, fractionated to different biochemical components, shows the rate of surplus energy accumulation, while net energy depletion shows the combustion rate of body reserves for metabolic needs. Results from different sampling periods have been combined to represent the main seasonal periods in nutritive conditions in the environment and/or the life-cycle of the amphipods which are observable in the benthic environment as changing nutritional conditions.

For zoobenthic species in general, the energetic value of the body matter of Monoporeld affunis falls at the high end of the scale (Griffiths 1977. Norrbin \& Bamstedt 1984, Brey et al. 1988), even if an ash level up to $10 \%$ is assumed. This accords with the statement made by Slobodkın \& Richman (1961) that organısms encountenng periods of food scarcity dunng their lifecycle have high mean energy content. The results imply that the amphupods in the present study area have adopted an energy storage strategy which ensures maxumum benefit from the short but intensive penod of the spring phytoplankton sedimentation

\section{Role of lipids in metabolism and reproduction}

In Monoporela affinis, lipids serve as a reserve of metabolic fuel and provide the main source of reproductuve energy. A compilation of studies on $M$. affinis, Pontoporeia femorata and Diporeia hoyi (Table 3) shows that lipid levels in these closely related species are unusually high compared to other benthic crustaceans (review by Griffiths 1977; see also Clarke et al 1985. Falkowskl et al. 1989, Napolitano \& Ackman 1989 ). In the present study, the seasonal range of 17 to $45 \%$ in the reproducing $2+$ yr olds is wider than that reported by Hill et al. (1992) from a northern Baltic coastal population, but the maximum levels equal 
those observed by Gardner et al. (1985a, b) and Gauvin et al. (1989) in Lake Michigan D. hoyi. The observed high lipid level of $M$. affinis secures a high reproductive potential as well as survival during poor food conditions.

Hill et al. (1992) recorded almost equal proportions of TAG and PL in Monoporeia affinis in the spring, while in the present study, TAG levels were always $\geq 70 \%$ of total lipids. The lipid and TAG levels of the $1+y r$ olds were always only slightly lower than in the $2+$ yr olds entering the reproductive phase; this implies that a high lipid level in $M$ affinis is not necessarily coupled with reproduction, as juveniles evidently accumulate lipid for overwintering. A similar life-strategy has been demonstrated for juveniles of the deep-water prawn Pandalus borealis (Hopkins et al. 1993).

The production of eggs is related to the lipid content of individuals. In the study area, fertilization in Monoporeia affinis takes place in late autumn and the offspring are usually released before March (e.g. Segerstråle 1959, Andersin \& Lehtonen unpubl.). The relation between lipid mass and body size seems to be a determining factor for the onset of the reproductive phase. It is suggested that the main reason why the $1+\mathrm{yr}$ olds at the study location do not reproduce despite a high lipid level is that the allocation of lipid for the development of reproductive tissue and eggs would result in serious starvation before brood release. Furthermore, low lipid content may reduce the viability of the offspring (Ouellet et al. 1992).

In this study, the lipid level of the $2+y r$ olds declined in late autumn. Hill et al. (1992) also noted a decrease in lipid levels of both male and female Monoporeia affinis, as well as of Pontoporeia femorata, in October. Allocation of lipids and especially of TAG in the elaboration of reproductive tissue has also been shown in krill (Falk-Petersen et al. 1981). During maturation, reduced or halted feeding accelerates the depletion of body lipid for maintenance metabolism. After fertilization, the progressively increasing metabolism of the developing embryos further reduces the total lipid/ TAG contents of the 'mother-brood complex'. In conclusion, lipid dynamics in $M$. affinis is intimately assoclated with the life strategy of the species.

\section{Bioenergetic characteristics of the study population}

During the periods when all the biochemical constituents studied show net accumulation (see Fig. 6), the sources of metabolic energy cannot be identified with the data abtained. However, the O:N ratio $\left(\mathrm{O}_{2}\right.$ consumption: $\mathrm{NH}_{4}{ }^{+}$excretion) is 50 to 60 during food abundance (Lehtonen 1994, 1996), denoting an almost equal use of lipids and protein (e.g. Mayzaud \& Conover 1988). These findings indicate that, in summer, substantial amounts of food protein are used to meet metabolic needs.

A high $O: N$ ratio of $>200$ (Lehtonen 1994, 1996) observed in Monoporeia affinis during winter-spring indicates an almost exclusive use of lipids and carbohydrates. The bioenergetic calculations presented in Fig. 6 demonstrate that, although growth is completely ceased (Andersin \& Lehtonen unpubl.), M. affinis obtains energy from the environment during winterspring. This is most conspicuous in the $1+\mathrm{yr}$ olds, where depleted body reserves supported only 11 and $19 \%$ (cohorts of 1990 and 1991, respectively) of their metabolic needs during this period (Fig. 6).

That the gravids of the 1989 cohort relied completely on the use of body reserves (Fig. 6) supports the previous observations of a cessation of feeding at the onset of maturation in Diporeia hoyi (Moore 1979, Quigley 1988 , Quigley et al. 1989). However, the gravids of cohort 1990 gained $60 \%$ of metabolic energy from the environment (Fig. 6), which confuses the proposed scheme.

Some of the aberrations in this bioenergetic model can be the result of loss of significant amounts of body material via ecdysis, most of the material belonging to the 'rest' fraction; however, it is probable that significant amounts of protein, lipid and chitin are resorbed from the old cuticle prior to moulting (Chandumpai et al. 1991 and citations within). Overestimation of the energy content of the 'rest' fraction, which also contains ash, can also cause bias, for example the observed $23 \%$ overshoot in energy loss in gravids of the 1989 cohort (Fig. 6).

\section{Bioenergetic strategy in relation to life-cycle and long-term oscillations in amphipod populations}

The life-cycle of Monoporeia affinis/Diporeia hoyi has generally been reported to be 1 to 2 yr (Segerstråle 1937, Green 1971, Winnell \& White 1984, Siegfried 1985, Uitto \& Sarvala 1991, Hill et al, 1992), but in the study area the population consists of at least 3 year classes (Andersin et al. 1984, Andersin \& Lehtonen unpubl.). The longevity of the amphipods has been associated with depth and temperature (Segerstråle 1937. Moore 1979, Leonardsson et al. 1988), and trophic conditions of the environment (Siegfried 1985).

In contrast to shallow, coastal areas, growth of $\mathrm{Mo}$ noporeia affinis in the study area is not temperatureregulated, since low temperature prevails throughout the season $\left(2.5\right.$ to $5^{\circ} \mathrm{C}$; Lehtonen 1996$)$, slowing metabolism and reducing the catabolism of energy reserves. In addition, reduced respiration rate during adverse food conditions [Lehtonen 1996; equivalent to 
Table 3. Reported lipid levels (\% dry weight) of Monoporeia affinis, Pontoporeia femorata and Diporeia hoyi. $\mathrm{F}=$ females $\mathrm{M}=$ males; $\mathrm{A}=$ adults (reproducing generation); $\mathrm{J}=$ juveniles [non-reproducing generation(s)]; $\mathrm{G}=$ gravids. From most studies, only the lowest and highest values are included

\begin{tabular}{|c|c|c|c|c|c|c|}
\hline Species & Location & Age/Sex & Lipid $(\%)$ & Month & Depth $(\mathrm{m})$ & Source \\
\hline D. hoyi & Lake Cayuga & A & 33.1 & Jun & 104 & Green (1971) \\
\hline D. hoyi & $\begin{array}{l}\text { Lake Ontario } \\
\text { Lake Erie }\end{array}$ & $\begin{array}{l}\text { A? } \\
\text { A? }\end{array}$ & $\begin{array}{l}24.1-32.5 \\
20.3\end{array}$ & $\begin{array}{l}? \\
?\end{array}$ & $?$ & $\begin{array}{l}\text { Whittle \& } \\
\text { Fitzsimons (1983) }\end{array}$ \\
\hline D. hoyi & Lake Michigan & $\begin{array}{l}\mathrm{J} \\
\mathrm{J}\end{array}$ & $\begin{array}{l}37.4^{\mathrm{d}} \\
28.7^{\mathrm{d}}\end{array}$ & $\begin{array}{l}\text { Aug } \\
\text { Aug }\end{array}$ & $\begin{array}{l}24 \\
45\end{array}$ & Gardner et al. (1985a) \\
\hline D. hoyi & Lake Michigan & $\begin{array}{l}J \\
J\end{array}$ & $\begin{array}{l}18.3^{\mathrm{a}} / 45.0^{\mathrm{a}} \\
18.3^{\mathrm{a} / 43.0^{\mathrm{a}}}\end{array}$ & $\begin{array}{l}\text { Mar/Jun } \\
\text { Mar/Sep }\end{array}$ & $\begin{array}{l}29 \\
45\end{array}$ & Gardner et al. (1985b) \\
\hline D. hoyi & Lake Michigan & $\begin{array}{l}J \\
F \\
M\end{array}$ & $\begin{array}{r}16.4 \\
22.7 \\
8.7\end{array}$ & $\begin{array}{l}\text { Dec } \\
\text { Dec } \\
\text { Dec }\end{array}$ & 45 & Quigley et al. (1989) \\
\hline P. femorata & $\begin{array}{l}\text { Jeddore Harbour, } \\
\text { Nova Scotia }\end{array}$ & $M$ & $12.0^{\circ}$ & Dec-Apr & $4-16^{r}$ & Paradis \& Ackman (1976) \\
\hline D. hoyi & Lake Michigan & A & $28.0 / 41.0$ & Dec/May & 45 & Gauvin et al. (1989) \\
\hline M. affinis & $\begin{array}{l}\text { Baltic Sea (coastal) } \\
\text { - Askö area }\end{array}$ & $\begin{array}{l}\mathrm{J} \\
\mathrm{A} \\
\mathrm{F} \\
\mathrm{M}\end{array}$ & $\begin{array}{c}11.0 / 19.0 \\
13.0 / 27.0 \\
19.0 \\
18.0\end{array}$ & $\begin{array}{l}\text { Sep/Aug } \\
\text { Mar/Jul } \\
\text { Oct } \\
\text { Oct }\end{array}$ & $30-40$ & Hill et al. (1992) \\
\hline P. femorata & & $\begin{array}{l}\mathrm{J} \\
\mathrm{A} \\
\mathrm{F} \\
\mathrm{M}\end{array}$ & $\begin{array}{l}12.0 / 16.0 \\
16.0 / 20.0-23.0 \\
19.0 \\
13.0\end{array}$ & $\begin{array}{l}\text { Aug/Oct } \\
\text { May/Rest of yed } \\
\text { Oct } \\
\text { Oct }\end{array}$ & & \\
\hline M. affinis & $\begin{array}{l}\text { Baltic Sea (open-sea) } \\
\text { - Bothnian Bay } \\
\text { - Bothnian Sea } \\
\text { - Gulf of Finland }\end{array}$ & $\begin{array}{l}\text { A } \\
A \\
A\end{array}$ & $\begin{array}{l}13.7-16.8 \\
33.0-37.2 \\
24.4-32.7\end{array}$ & $\begin{array}{l}\text { Jun } \\
\text { Jun } \\
\text { Jun }\end{array}$ & $\begin{array}{l}70-112 \\
77-212 \\
51-60\end{array}$ & Lehtonen (1995) \\
\hline & - Bothnian Sea & $\begin{array}{l}J \\
A \\
G\end{array}$ & $\begin{array}{l}22.0 / 41.5 \\
21.4 / 43.8 \\
16.8 / 26.8\end{array}$ & $\begin{array}{l}\text { May/Aug } \\
\text { Apr/Aug } \\
\text { Mar/Mar }\end{array}$ & 125 & This study \\
\hline \multicolumn{7}{|c|}{$\begin{array}{l}\text { 'Recalculated from ash-free dry weight (factor } 0.87 \text { ) } \\
{ }^{\circ} \text { Recalculated from wet weight (assuming } 75 \% \text { water content) } \\
\text { 'Collected from. stomachs of smelt Osmerus mordax }\end{array}$} \\
\hline
\end{tabular}

respiration measured under experimental starvation conditions (Lehtonen 1994)] further contributes to the conservation of energy. The varying life-cycles observed between coastal and open-sea $M$. affinis populations are probably a result of both nutritional and temperature conditions, which induce different bioenergetic strategies in populations inhabiting different sea areas.

Long-term oscillations (ca 7 yr cycle) in Monoporeia affinis populations (Andersin et al. 1978) almost certainly are connected to interannual variability in benthic nutritional conditions. The amphipods collected in winter and spring 1991 were smaller $(2+$ yr olds: mean dry wt $-1.0 \mathrm{mg}$, gravids: $-3.0 \mathrm{mg}$ ) than at a corresponding time in 1992 and $1993(2+$ yr olds: $~ 1.5 \mathrm{mg}$, gravids: $\sim 4.5 \mathrm{mg}$ ) (Andersin \& Lehtonen unpubl.). During spring 1992 and 1993, the seasonally characteristic biochemical condition of the amphipods was almost identical and all the condition parameters studied indicated a healthier physiological state than in spring 1991. Evidently 1990 was nutritionally unfavourable for amphipods in this area.

In addition to the direct effects of interannual variability in the quantity and quality of sedimented particulate matter, interspecific relations (e.g. predation by demersal fish and the isopod Saduria entomon, processing of food by micro- and meiofauna) play a part in the population dynamics of Monoporeia affinis. Density-dependent regulation of population size, especially in nutrition-limited areas, may also be behind the oscillations. In considering the observed variability in the body condition of the amphipods, results indicate that there exists a physiological, lipid-related 'buffering capacity' in effect against years of limited food resources, caused by variations in the species composition and biomass of the spring bloom in the northern 
Baltic Sea (e.g. Heiskanen \& Kononen 1994). Assuming this scheme, a marked collapse in the population is likely only if 2 or more poor years follow successively Together with environmental conditions, bioenergetic adaptations play an important role in the fluctuations in $M$. affinis populations.

Acknowledgements. This study was performed at the Finnish Institute of Marine Research under the Finnish-Swedish cooperative project 'The Gulf of Bothnia Year 1991' The author especially thanks Ann-Britt Andersin, M.Sc, and the rest of the FIMR Benthos Group for help and support. Ms Tuovi Vartio performed the elemental analyses with skill and experience. Comments by Drs Michael Quigley and Joann Cavaletto (Great Lakes Environmental Research Laboratory, Michigan) and 3 anonymous referees helped to improve the paper. Mr Richard Thompson Coon (Gulf of Finland Environment Society) corrected the English.

\section{LITERATURE CITED}

Andersin AB, Lassig J, Parkkonen L, Sandler H (1978) Longterm fluctuations of the soft bottom macrofauna in the deep areas of the Gulf of Bothnla 1954-1974, with special reference to Pontoporeia affinis Lindström (Amphipoda). Finn Mar Res 244:137-144

Andersin AB, Lassig J, Sandler H (1984) On the biology and production of Pontoporeia affinis Lindstr in the Gulf of Bothnia. Limnologica 15:395-401

Andersson A, Rudehäll $\AA$ (1993) Proportion of plankton biomass in particulate organic carbon in the northern Baltic Sea. Mar Ecol Prog Ser 95:133-139

Ankar S, Elmgren R (1975) A survey of the benthic macroand meiofauna of the Asko-Landsort area. Merentutkimuslait Julk 239:257-264

Ansell AD (1974) Seasonal changes in biochemical composition of the bivalve Abra alba from the Clyde Sea area. Mar Biol 25:13-20

Berges JA, Fisher AE, Harrison PJ (1993) A comparison of Lowry, Bradford and Smith protein assays using different protein standards and protein isolated from the marine diatom Thalassiosira pseudonata. Mar Biol 115:187-193

Bousfield EL (1989) Revised morphological relationships within the amphipod genera Pontoporeia and Gammaracanthus and the 'glacial relict' significance of their postglacial distributions. Can J Fish Aquat Sci 46:1714-1725

Bradford MM (1976) A rapid and sensitive method for quantitation of microgram quantities of protein utilizing the principle of protein dye binding. Analyt Biochem 72: $248-254$

Brey T, Rumohr H, Ankar S (1988) Energy content of macrobenthic invertebrates: general conversion factors from weight to energy. J Exp Mar Biol Ecol 117:271-278

Cederwall $H$ (1977) Annual macrofauna production of a soft bottom in the northern Baltic Proper. In: Keegan BF, Céidigh PÓ, Boaden PJS (eds) Biology of benthic organisms. 11th Europ Symp Mar Biol. Pergamon Press, Oxford, p $155-164$

Chandumpai A, Dall W, Smith DM (1991) Lipid-class composition of organs and tissues of the tiger prawn Penaeus esculentus during the moulting cycle and during starvation. Mar Biol 108:235-245

Christensen H, Kanneworff E (1985) Sedimenting phytoplankton as major food source for suspension and deposit feeders in the Øresund. Ophelia 24:223-244
Clarke A, Skadsheim A, Holmes LJ (1985) Lipid biochemustry and reproductive biology in two species of Gammaridae (Crustacea: Amphipoda). Mar Biol 88:247-263

Elliott JM, Davison W (1975) Energy equivalents of oxygen consumption in animal energetics. Oecologia (Berlin) 19 $195-201$

Elmgren R (1978) Structure and dynamics of Baltic benthos communities, with particular reference to the relationship between macro- and meiofauna. Kieler Meeresforsch, Sonderh $4: 1-22$

Falkowski L, Polak L, Jarzebski A (1989) Lipıd compositıon of Crustacea from the Gulf of Gdansk. In: Klekowski RZ. Styczynska-Jurewicz E, Falkowski L (eds) Proceedings of the 21st European Marine Biology Symposium. Ossolineum, Gdansk, p 53-57

Falk-Petersen S, Gatten RR, Sargent JR, Hopkins CCE (1981) Ecological investigations on the zooplankton community in Balsfjorden, northern Norway: seasonal changes in the lipid class composition of Meganyctiphanes norvegica (M. Sars). Thysanoessa raschii (M. Sars), and $T$ inermis (Krøyer). J Exp Mar Biol Ecol 54:209-224

Fitzgerald SA, Gardner WS (1993) An algal carbon budget for pelagic-benthic coupling in Lake Michigan. Limnol Oceanogr 38:547-560

Gardner WS, Frez WA, Cichocki EA, Parrish CC (1985a) Micromethod for lipids in aquatic invertebrates. Limnol Oceanogr 30:1099-1105

Gardner WS, Nalepa TF, Frez WA, Cichocki EA, Landrum PF (1985b) Seasonal patterns in lipid content of Lake Michigan macroinvertebrates. Can J Fish Aquat Sci 42: $1827-1832$

Gatten RR, Sargent JR, Forsberg TEV, O'Hara SCM, Corner EDS (1980) On the nutrition and metabolism of zooplankton. XIV. Utilization of lipid by Calanus helgolandicus during maturation and reproduction. J Mar Biol Ass UK 60: $391-399$

Gauvin JM, Gardner WS, Quigley MA (1989) Effects of food removal on nutrient release rates and lipid content of Lake Michigan Pontoporeia hoyi. Can J Fish Aquat Sci 46 $1125-1130$

Gnaiger E (1983) Calculation of energetic and biochemical equivalents of respiratory oxygen consumption. In Gnaiger E, Forstner H (eds) Polarographic oxygen sensors Springer-Verlag, Berlin, p 337-345

Green RH (1971) Lipid and caloric contents of the relict amphipod Pontoporeia affinis in Cayuga Lake, New York. J Fish Res Bd Can 28:776-777

Griffiths D (1977) Caloric variation in Crustacea and other animals. J Anim Ecol 46:593-605

Heiskanen AS, Kononen K (1994) Sedimentation of vernal and late summer phytoplankton communities in the coastal Baltic Sea. Arch Hydrobiol 131:175-198

Hill C, Quigley MA, Cavaletto JF, Gordon W (1992) Seasonal changes in lipid content and composition in the benthic amphipods Monoporeia affinis and Pontoporeia femorata. Limnol Oceanogr 37:128

Hopkins CCE, Sargent JR, Nilssen EM (1993) Total lipid content, and lipid and fatty acid composition of the deepwater prawn Pandalus borealis from Balsfjord, northern Norway: growth and feeding relationships. Mar Ecol Prog Ser 96:217-228

Johnson RK, Wiederholm T (1992) Pelagic-benthic coupling - the importance of diatom interannual variability for population oscillations of Monoporeia affinis. Limnol Oceanogr 37:1596-1607

Kuparinen J, Leppänen JM, Sarvala J, Sundberg A, Virtanen A (1984) Production and utilization of organic matter in a 
Baltic ecosystem off Tvärminne, southwest coast of Finland. Rapp PV Réun Cons Int Explor Mer 183:180-192

Lassig J, Leppanen JM, Niemi A, Tamelander G (1978) Phytoplankton primary production in the Gulf of Bothnia in 1972-1975 as compared with other parts of the Baltic Sea. Finn Mar Res 244:101-115

Lehtonen KK (1994) Metabolic effects of short-term starvation on the benthic amphipod Pontoporeia affinis Lindström from the northern Baltic Sea. J Exp Mar Biol Ecol 176: 269-283

Lehtonen KK (1995) Geographical variability in the bioenergetic characteristics of Monoporeia/Pontoporeia spp. populations from the northern Baltic Sea, and their potential contribution to benthic nitrogen mıneralization. Mar Biol 123:555-564

Lehtonen KK (1996) Ecophysiology of the benthic amphipod Monoporeia affinis in an open-sea area of the northern Baltic Sea: seasonal variations in oxygen consumption and ammonia excretion. Mar Biol (in press)

Leonardsson K, Sörlin T, Samberg H (1988) Does Pontoporeia affinis (Amphipoda) optimize age at reproduction in the Gulf of Bothnia? Oikos 52:328-336

Leppänen JM (1988) Cycling of organic matter during the vernal growth period in the open northern Baltic proper. VI. Sinking of particulate matter. Finn Mar Res 255: $97-118$

Lowry OH, Rosebrough NJ, Farr AL, Randall RJ (1951) Protein measurement with the Folin phenol reagent. J Biol Chem 193:265-275

Mayzaud P, Conover RJ (1988) O:N atomic ratio as a tool to describe zooplankton metabolism. Mar Ecol Prog Ser 45: 289-302

Moore JW (1979) Ecology of a subarctic population of Pontoporeia affinis Lindström (Amphipoda). Crustaceana 36: $267-276$

Napolitano GE, Ackmann RG (1989) Lipids and hydrocarbons in Corophium volutator from Minas Basin, Nova Scotia. Mar Biol 100:333-338

Norrbin F, Bamstedt U (1984) Energy contents in benthic and planktonic invertebrates of Kosterfjorden, Sweden. Ophelia $23: 47-64$

O'Connor NJ (1992) Influence of dietary nitrogen on the body chemical composition of the salt-marsh fiddler crabs Uca pugilator and U. pugnax. Bull Mar Sci 50:404-410

Ouellet P. Taggert CT. Frank KT (1992) Lipid condition and survival in shrimp Pandalus borealis larvae. Can J Fish Aquat Sci 49:368-378

Paradis M, Ackman RG (1976) Localization of a marine source of odd chain-length fatty acids. I. The amphipod Pontoporeia femorata (Kröyer). L.ipids 11:863-870

This article was submutted to the editor
Quigley MA (1988) Gut fullness of the deposit-feeding amphipod, Pontoporeia hoyi, in southeastern Lake Michigan. J Great Lakes Res 15:601-610

Quigley MA, Chandler JF, Gardner WS (1989) Lipid composition related to body size and maturity of the amphipod Pontoporeia hoyi. J Great Lakes Res 15:601-610

Sargent JR, Henderson RJ (1986) Lipids. In: Corner EDS, O'Hara SCM (eds) The biological chemistry of marine copepods. Clarendon Press, Oxford, p 59-108

Sarvala J (1986) Interannual variation of growth and recruitment in Pontoporeia affinis (Lindstrom) (Crustacea: Amphipodal in relation to abundance fluctuations. J Exp Mar Biol Ecol 101:41-59

Segerstrăle SG (1937) Studien über die Bodentierwelt in südfinnländischen Küstengewässern III. Zur Morphologie und Biologie des Amphipoden Pontoporeia affinis, nebst einer Revision der Pontoporeia-Systematik. Soc Scient Fenn Comment Biol 7:1-181

Segerstråle SG (1959) Synopsis of data on the crustaceans Gammarus locusta, Gammarus oceanus, Pontoporeia affinis, and Corophium volutator (Amphipoda, Gammaridea). Soc Scient Fenn Comment Biol 20:1-23

Siegfried CA (1985) Life history, population dynamics and production of Pontoporeia hoyi (Crustacea, Amphipoda) in relation to the trophic gradient of Lake George, New York. Hydrobiologia 122:175-180

Slobodkin LB, Richman S (1961) Calories/gm in species of animals. Nature (London) 191:299

Solórzano L (1969) Determination of ammonia in natural waters by the phenolhypochlorite method. Limnol Oceanogr 14:799-801

Tenore KR (1977) Growth of Capitella capitata cultured on various levels of detritus derived from different sources Limnol Oceanogr 22:936-941

Tsutsumi H, Fukunaga S, Fujita N, Sumida M (1990) Relationship between growth of Capitella sp. and organic enrichment of the sediment. Mar Ecol Prog Ser 63:157-162

Uitto A, Sarvala J (1991) Seasonal growth of the benthic amphipods Pontoporeia affinis and $P$. femorata in a Baltic archipelago in relation to environmental factors. Mar Biol $111: 237-246$

Whittle DM, Fitzsimons JD (1983) The influence of the Niagara River on contaminant burdens of Lake Ontario biota. J Great Lakes Res 9: 295-302

Winberg GG (1971) Methods for the estimation of production of aquatic animals. Academic Press, London

Winnell MH. White DS (1984) Ecology of shallow and deep water populations of Pontoporeia hoyi (Smith) (Amphipoda) in Lake Michigan. Freshwater Invertebr Biol 3 $118-138$

Manuscript first recelved: January 12, 1996

Revised version accepted: September 9, 1996 